\title{
SALT WORKS AND THEIR IMPACT ON SOIL AND GROUNDWATER. THE CASES OF ANGELOHORI AND KITROS, GREECE
}

\author{
CHRISTODOULOS ANGELOPOULOS ${ }^{1}$, EVANGELOS NICOLAOU ${ }^{2}$
}

\begin{abstract}
Contamination of soil and groundwater caused to salt works occurs due to infiltration of a part of seawater from the lakes of salt works through the soil and into phreatic aquifers and from there percolating to artesian aquifers. In the same time, while salt remaining in place is washed out by rain, contaminating soil and both phreatic and artesian aquifers. In the areas of Angelohori and Kitros this contamination of soil has been detected through chemical analysis while groundwater contamination has been suggested through pressure level contours.
\end{abstract}

KEY WORDS: Salt work, seawater intrusion, soil contamination, groundwater contamination, pressure level contours.

\section{PREFACE}

In Greece salt is obtained from marine water, as in many other countries with lack of ore salt, which they dispose of extended seashore. Seawater is conducted to special arranged lakes, with a rectangular shape, by the use of some channels digged on the beach (Fig. 1). These lakes are called salt works and they are of low depth, where through water evaporation salt remains in place. After salt is precipitated is carried away in order to be rafinated, so as to be distributed in the market.

This process represents a potential hazard for the environment, due to contamination of groundwater with seawater.

\section{THE GROUNDWATER - SEAWATER INTERFACE}

Along coastal areas seawater and groundwater comes into contact. These two liquids have different densities and they cannot be mixed. Instead an interface is formed between the two liquids, which has a shape, established by the hydrodynamic balance along the contact plan. This interface has an inclination towards land and its toe intersects the bottom of the aquifer (Fetter, 1972, Kallergis, 1986, Todd, 1974)(Fig. 2).

Due to overdraft of water wells, the seawater - groundwater interface is moving towards land, developing thus an intrusion of seawater into groundwater (Fetter, 1972, Kallergis, 1986). This intrusion is presented both as an advance of the whole interface towards land and an uplifting of the interface in the areas of overdraft, interface thickness being increased (Fig. 2).

${ }^{1}$ Geologist Engineer - Envicon Consultants, Melenikou 30, 54842 Thessaloniki, Greece

${ }^{2}$ Geologist Engineer, Dr. in Hydrogeology, I.G.M.E., Preveza, Greece 
CHRISTODOULOS ANGELOPOULOS, EVANGELOS NICOLAOU

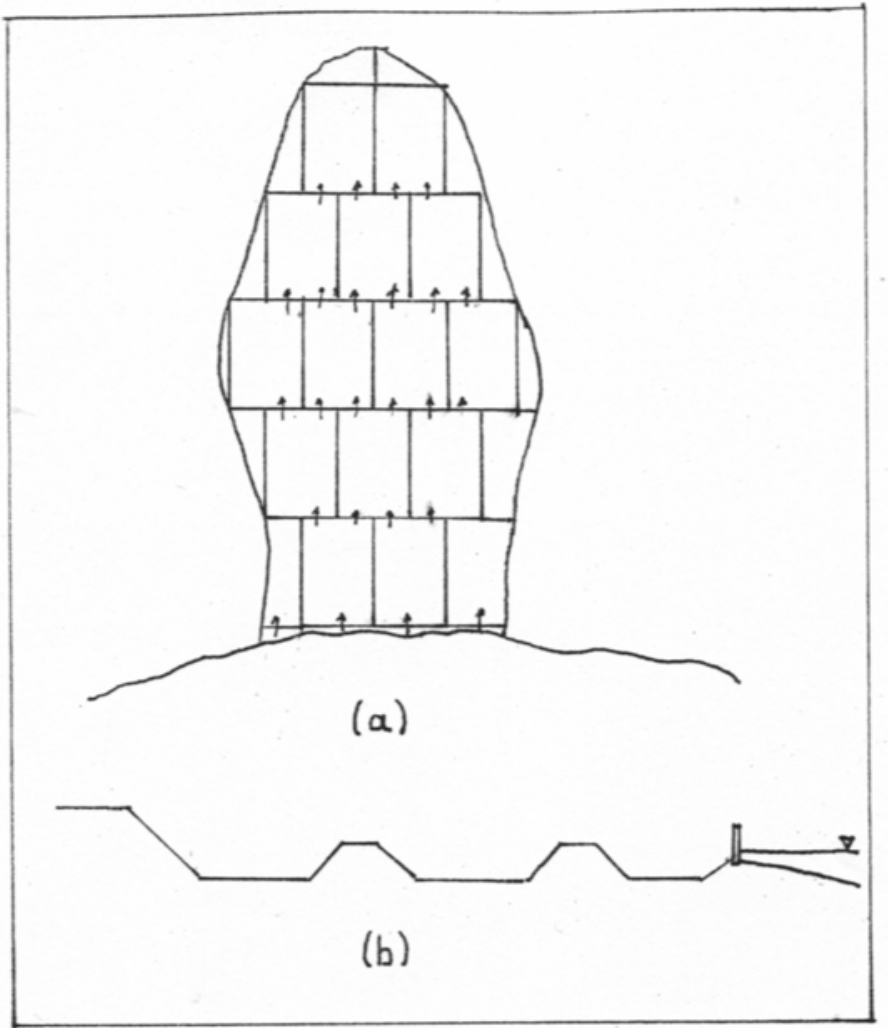

Fig. 1: View of a salt work: (a) plane view and (b) longitudinal view

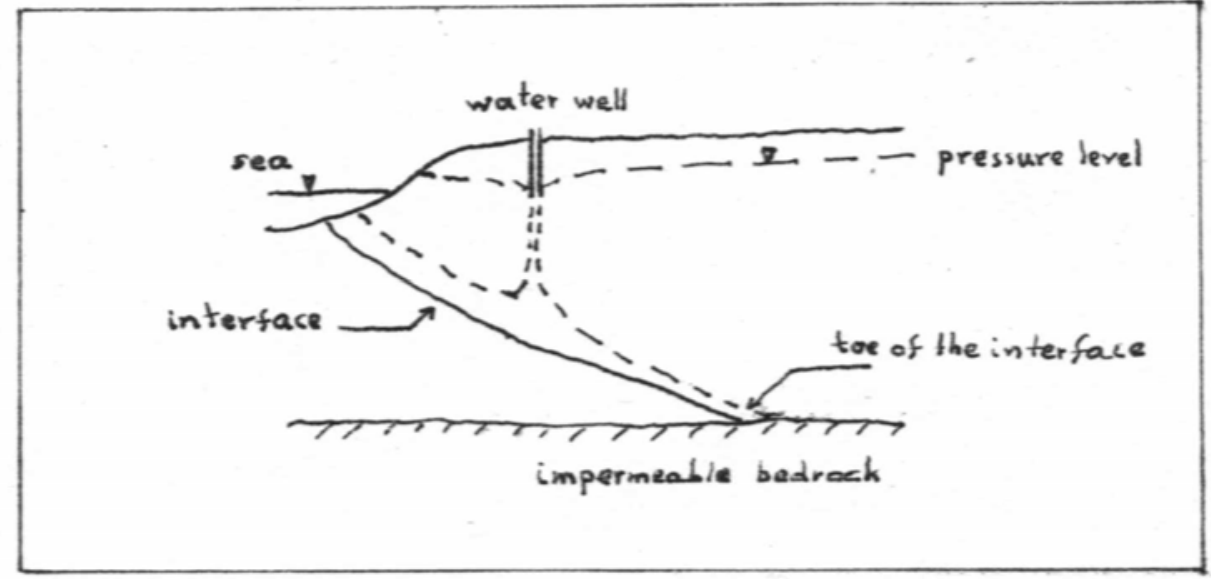

Fig. 2: The groundwater - seawater interface and the seawater intrusion (Kallergis, 1986 - with modifications) 
Fresh water aquifers are consequently contaminated with ions of chlorine, sodium and potassium, hence water becomes inadequate for drinking and sometimes for irrigating purposes.

This intrusion has been observed, almost in every coastal area worldwide (Fetter, 1972, Todd, 1974). In Greece, due to its long coast and the vast number of islands, seawater invasion is taking place along almost all coasts and all islands (Kallergis, 1986).

\section{CONTAMINATION OF SOIL AND GROUNDWATER}

Contamination of soil and groundwater caused to salt works occurs due to infiltration of a part of seawater from the lakes of salt works through the soil and into phreatic aquifers. From there saline water is percolated to artesian aquifers. In the same time, while seawater from the lakes is evaporated, salt remains in place and is washed out by rain, whence is infiltrated in the ground as a saline water, contaminating both phreatic and artesian aquifers.

The fact that most coasts are composed of permeable deposits allows saline water to infiltrate easily. Thus soils present increased salinity and fresh groundwater becomes brackish or saline.

Salinisation of soil caused by salt works can be detected by chemical analysis of samples collected from the ground. The results of chemical analysis show an increase in chlorine, sodium and potassium, which cannot be caused by the intrusion of seawater into groundwater.

Salinisation of groundwater caused by salt works can also be detected by chemical analysis of samples collected from nearby wells, but it cannot be directly connected to salt works, because it cannot be distinguished from saltwater contamination caused by the intrusion of seawater into groundwater.

In this case the only way to identify the source of salinisation is by using either water table contours, in case of an unconfined aquifer, or pressure level contours in case of a confined aquifer. An elevation of the water table or pressure level less than $5 \mathrm{~m}$ indicates the beginning of salinisation of fresh water, while the corresponding elevation of $0 \mathrm{~m}$ indicates the front of seawater intrusion, that is the site of the seawater - freshwater interface.

In case of a salinisation of fresh water due to salt works the water table contours or pressure level contours having an elevation of 5 and $0 \mathrm{~m}$ must be considerably removed towards inland, in the area of the salt work, in comparison with the rest of the coastal area. Some intrusion of this front has often detected in the areas of overdrafting wells, but in any case are of a smaller extend compared with those caused by contamination from salt works.

\section{THE CASE OF ANGELOHORI, GREECE}

Angelohori is situated to $25 \mathrm{Km}$ south-east of Thessaloniki. Adjacent to the settlement a salt work exists, which was operated until recently. The small lakes have been unified in a large one, occupying an area of $5,5 \mathrm{Km}^{2}$. Coastal area is almost plain, having a very small inclination towards sea. 
The coastal area of Angelohori consists of the following geological formations, from the more recent to older (I.G.M.E., 1969, Steffens et al, 1979):

Red silt, sands and clayey sands (Quaternary): they cover the coastal area, reaching the depth of $18 \mathrm{~m}$; these deposits dispose of an average permeability, allowing infiltration to groundwater (Papageorgakis \& Koumantakis, 1978).

Sands, cobbles, pebbles and calcareous marbles (Quaternary): they extend to the depth of $100 \mathrm{~m}$; in these deposits an aquifer is formed, consisting of several subsequent levels (Kilili-Polychronaki, 1973, Papageorgakis \& Koumantakis, 1978).

Red clays, sandy clays and marbles (Neogene): they are found in the base of the succession reaching the depth of at least $250 \mathrm{~m}$; these deposits also dispose of an aquifer (Kilili-Polychronaki, 1973, Papageorgakis \& Koumantakis, 1978).

In order to study contamination of soil, a sample of soil has been collected from the salt work area and two from the surrounding area and chemical analysis was carried out (Table 1). Based on concentration of chlorine, sodium and potassium, soil in the area of salt work has proved to be contaminated with saline water, found to be of an increased salinity. The concentration of chlorine, sodium and potassium is considerably increased compared with normal accepted values for soils. It is obvious therefore that concentration of these ions in the area of salt work is considerably increased considering that of the rest of the coastal area.

Table 1

Chemical analysis of soil samples from the Angelohori area

\begin{tabular}{|c|c|c|c|c|c|c|}
\hline & \multicolumn{2}{|c|}{ SA1 } & \multicolumn{2}{|c|}{ SA2 } & \multicolumn{2}{|c|}{ SA3 } \\
\hline & $\mathrm{mg} / \mathrm{l}$ & $\mathrm{meq} / \mathrm{l}$ & $\mathrm{mg} / \mathrm{l}$ & $\mathrm{meq} / \mathrm{l}$ & $\mathrm{mg} / \mathrm{l}$ & $\mathrm{meq} / \mathrm{l}$ \\
\hline \multicolumn{7}{|c|}{ Cations } \\
\hline $\mathrm{Na}^{+}$ & $22.655,0$ & 985,0 & $1.384,6$ & 60,2 & 92,0 & 4,0 \\
\hline $\mathrm{K}^{+}$ & 84,7 & 2,2 & 27,4 & 0,7 & 7,8 & 0,2 \\
\hline $\mathrm{Ca}^{++}$ & 212,0 & 10,6 & 250,0 & 12,5 & 78,0 & 3,9 \\
\hline $\mathrm{Mg}^{++}$ & 202,5 & 16,6 & 132,9 & 10,9 & 32,9 & 2,7 \\
\hline \multicolumn{7}{|c|}{ Anions } \\
\hline $\mathrm{Cl}^{-}$ & $37.452,5$ & $1.055,0$ & $2.442,4$ & 68,8 & 177,5 & 5,0 \\
\hline $\mathrm{SO}_{4}^{-}$ & $2.294,4$ & 47,8 & 427,2 & 8,9 & 24,0 & 0,5 \\
\hline $\mathrm{HCO}_{3}^{-}$ & 164,7 & 2,7 & 323,3 & 5,3 & 323,3 & 5,3 \\
\hline
\end{tabular}

In order to study contamination of groundwater one sample of groundwater had been collected and chemical analysis was carried out (Table 2). According to concentration of chlorine, sodium and potassium, groundwater is contaminated with saline water.

On the other hand pressure level measurements had been performed in the wells of the surrounding area and the elevation (Table 3 ). The pressure level contours were subsequently drawn (Fig. 3). 
Table 2

Chemical analysis of groundwater sample from the Angelohori area (A1)

\begin{tabular}{|l|r|r|}
\hline & $\mathbf{m g} / \mathbf{l}$ & $\mathbf{~ m e q} / \mathbf{l}$ \\
\hline Cations & 253,29 & 11,01 \\
\hline $\mathrm{Na}^{+}$ & 31,93 & 0,82 \\
\hline $\mathrm{K}^{+}$ & 99,26 & 4,96 \\
\hline $\mathrm{Ca}^{++}$ & 28,18 & 2,31 \\
\hline $\mathrm{Mg}^{++}$ & 470,62 & 13,25 \\
\hline Anions & 24,08 & 0,71 \\
\hline $\mathrm{Cl}^{-}$ & 498,22 & 8,17 \\
\hline $\mathrm{SO}_{4}{ }^{--}$ & \multicolumn{2}{|l|}{} \\
\hline $\mathrm{HCO}_{3}{ }^{-}$ & \multicolumn{2}{|c|}{} \\
\hline
\end{tabular}

Table 3

Pressure level measurements in the area of Angelohori (September 2002)

\begin{tabular}{|c|c|}
\hline Well & Pressure level elevation (m) \\
\hline A1 & 0,3 \\
\hline A2 & 2,7 \\
\hline A3 & 5,9 \\
\hline A4 & 8,2 \\
\hline A5 & 4,1 \\
\hline A6 & 3,8 \\
\hline A7 & 2,2 \\
\hline A8 & 0,2 \\
\hline A9 & 8,7 \\
\hline
\end{tabular}

According to pressure level contours an intrusion of the 0 and $5 \mathrm{~m}$ elevations is observed, which suggests a contamination due to salt works. In the rest of the coastal area contamination due to seawater intrusion is shown.

\section{THE CASE OF KITROS, GREECE}

Kitros is situated $45 \mathrm{Km}$ south-west of Thessaloniki and $15 \mathrm{Km}$ northeast of Katerini. Adjacent to the settlement of Kitros a salt work exists fully operating, in an area of $2,5 \mathrm{Km}^{2}$. The lakes of the salt work have a depth of 8$40 \mathrm{~cm}$. The surrounding area of $10 \mathrm{Km}^{2}$ is transformed into a wetland. Coastal area is almost plain, having a very small inclination towards sea.

The coastal area of Kitros consists of the following geological formations, from the more recent to older (I.G.M.E., 1986, Psilovikos, 1985):

Sands and silts (Quaternary): they cover the coastal area, reaching the depth of $18 \mathrm{~m}$; these deposits dispose of an average permeability, allowing infiltration to groundwater. 


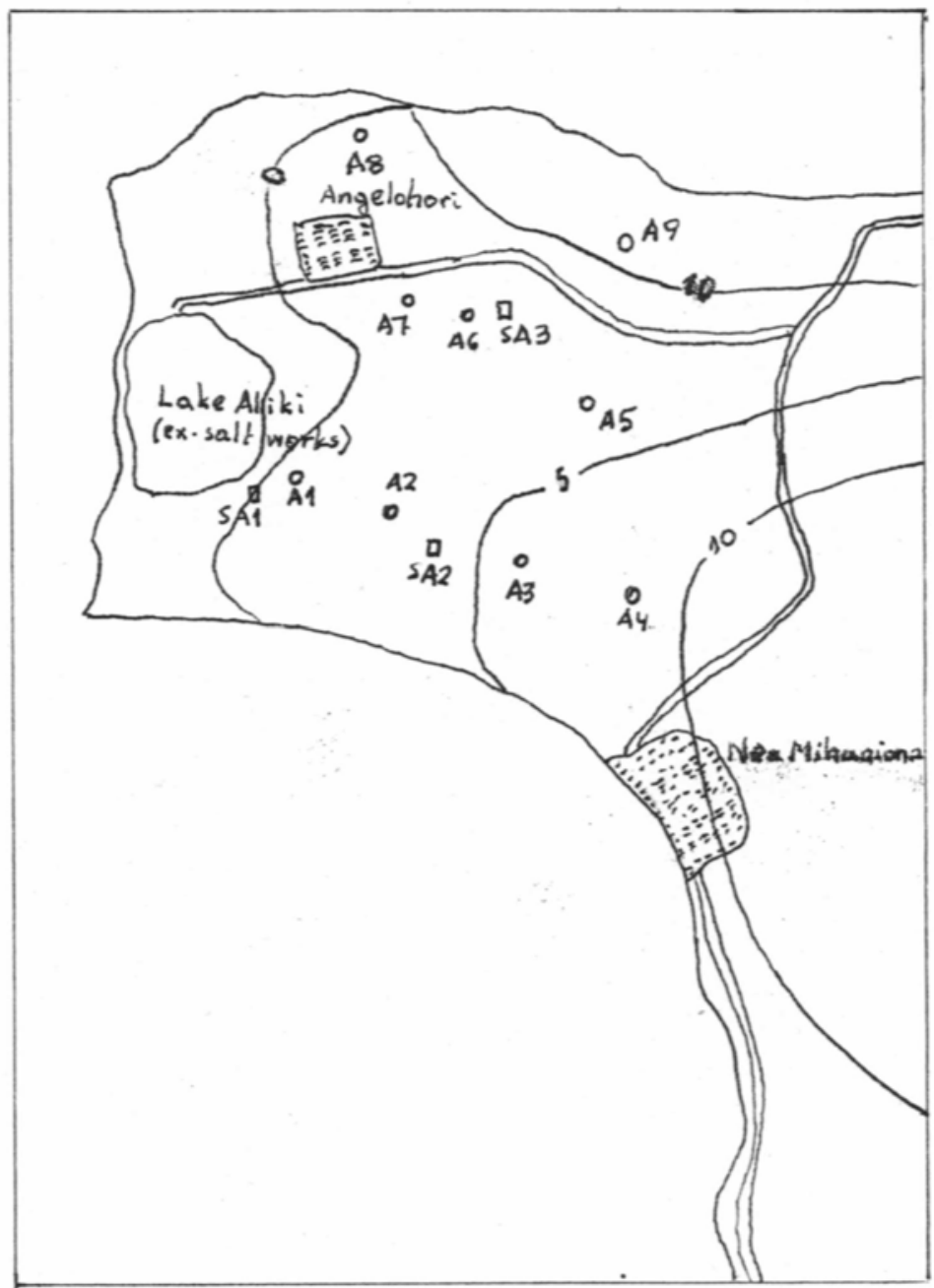

Fig. 3: Pressure level contours in the area of Angelohori

Wetland deposits (Quaternary): they consist of clays, clayey sands and silts; they cover the area of wetland.

Sandstone and clay deposits (Neogene): they consist of coarse to fine sandstone in alternation with clays, having a thickness of $600 \mathrm{~m}$; in these deposits an aquifer is formatted, consisting of several subsequent levels (Konstantinidis, 1985).

In order to study contamination of soil, a sample of soil had been collected from the salt work area and two from the surrounding area and chemical analysis was carried out (Table 4). Based on concentration of chlorine, sodium and potassium, soil in the area of salt work has proved to be contaminated 8 
with saline water, found to be of an increased salinity. The concentration of chlorine, sodium and potassium is considerably increased compared with normal accepted values for soils. It is obvious therefore that concentration of these ions in the area of salt work is considerably increased considering that of the rest of the coastal area.

\section{Table 4}

Chemical analysis of soil samples from the Kitros area

\begin{tabular}{|l|r|r|r|r|r|r|}
\hline & \multicolumn{2}{|c|}{ SK1 } & \multicolumn{2}{c|}{ SK2 } & \multicolumn{2}{c|}{ SK3 } \\
\hline & $\mathrm{mg} / \mathrm{l}$ & $\mathrm{meq} / \mathrm{l}$ & $\mathrm{mg} / \mathrm{l}$ & $\mathrm{meq} / \mathrm{l}$ & $\mathrm{mg} / \mathrm{l}$ & $\mathrm{meq} / \mathrm{l}$ \\
\hline Cations & 33.005 & 1435,0 & 287,5 & 12,5 & 207,0 & 9,0 \\
\hline $\mathrm{Na}^{+}$ & 11.417 & 292,0 & 46,9 & 1,2 & 3,9 & 0,1 \\
\hline $\mathrm{K}^{+}$ & 920 & 46,0 & 100,0 & 5,0 & 44,0 & 2,2 \\
\hline $\mathrm{Ca}^{++}$ & 20 & 1,6 & 37,8 & 3,1 & 15,9 & 1,3 \\
\hline $\mathrm{Mg}^{++}$ & \multicolumn{7}{|l|}{} \\
\hline Anions $^{-}$ & 61.237 & 1725,0 & 667,4 & 18,8 & 177,5 & 5,0 \\
\hline $\mathrm{Cl}^{-}$ & 2.208 & 46,0 & 446,4 & 9,3 & 0,0 & 0,0 \\
\hline $\mathrm{SO}_{4}{ }^{--}$ & 207 & 3,4 & 347,7 & 5,7 & 567,3 & 9,3 \\
\hline $\mathrm{HCO}_{3}^{-}$ &
\end{tabular}

In order to study contamination of groundwater one sample of groundwater had been collected and chemical analysis was carried out (Table 5). According to concentrantion of chlorine, sodium and potassium groundwater is contaminated with saline water.

Table 5

Chemical analysis of groundwater sample from the Kitros area (K1)

\begin{tabular}{|l|r|r|}
\hline & $\mathbf{m g} / \mathbf{l}$ & $\mathbf{m e q} / \mathbf{l}$ \\
\hline Cations & 223,12 & 9,70 \\
\hline $\mathrm{Na}^{+}$ & 29,72 & 0,76 \\
\hline $\mathrm{K}^{+}$ & 94,4 & 4,72 \\
\hline $\mathrm{Ca}^{++}$ & 21,35 & 1,75 \\
\hline $\mathrm{Mg}^{++}$ & 453,69 & 12,78 \\
\hline Anions & 34,07 & 0,71 \\
\hline $\mathrm{Cl}^{-}$ & 459,44 & 7,53 \\
\hline $\mathrm{SO}_{4}^{--}$ &
\end{tabular}

On the other hand pressure level measurements had been performed in the wells of the surrounding area and transformed in elevation values (Table 6). The pressure level contours were subsequently drawn (Fig. 4).

According to pressure level contours an intrusion of the 0 and $5 \mathrm{~m}$ elevations is observed, which suggests a contamination due to salt works. In the rest of the coastal area contamination due to seawater intrusion is shown. 
CHRISTODOULOS ANGELOPOULOS, EVANGELOS NICOLAOU

\section{Table 6}

Pressure level measurements in the area of Kitros

(September 2002)

\begin{tabular}{|c|c|}
\hline Well & Pressure level elevation $(\mathrm{m})$ \\
\hline $\mathrm{K} 1$ & 0,2 \\
\hline $\mathrm{K} 2$ & 7,4 \\
\hline $\mathrm{K} 3$ & 6,2 \\
\hline $\mathrm{K} 4$ & 10,6 \\
\hline $\mathrm{K} 5$ & 6,8 \\
\hline $\mathrm{K} 6$ & 2,3 \\
\hline
\end{tabular}

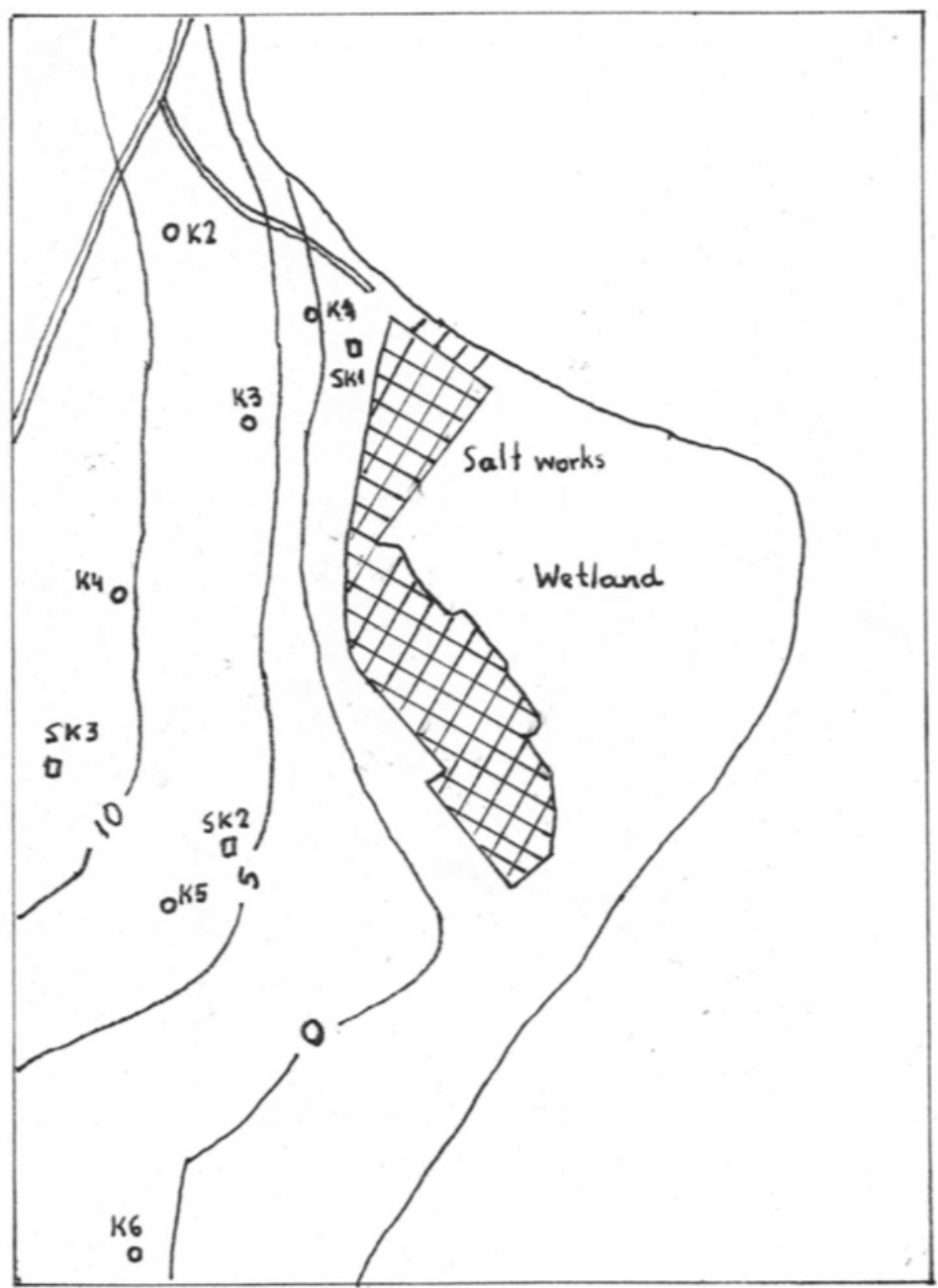

Fig. 4: Pressure level contours in the area of Kitros (Scale 1:50.000) 


\section{CONCLUSIONS}

Soil chemical analysis performed in the area of Angelohori and Kitros revealed an intense contamination from salt water due to salt works.

Chemical analysis of grounwater suggests contamination of groundwater, but without specifying whether the source of this contamination is seawater intrusion or infiltrated water from salt works.

The measurement of pressure level elevation in waterwells and the construction of the relevant contours indicate that the source of groundwater contamination is salt works activity. This conclusion results from the fact that even though there is only one well in both salt works areas, without being overdraft, pressure level contours show an increased intrusion of seawater, in comparison with adjacent coastal areas, which cannot been explained by seawater intrusion.

\section{REFERENCES}

Fetter, C. W., 1972, Position of the saline water interface beneath oceanic islands, Water Resources Research, V. 8, p. 1307-1315, New York.

Institute of Geological and Mineral Exploration (I.G.M.E.), 1969, Geological map of Greece, Scale 1:50.000, Page Epanomi, Athens.

Institute of Geological and Mineral Exploration (I.G.M.E.), 1986, Geological map of Greece, Scale 1:50.000, Page Katerini, Athens.

Kallergis, G., 1986, Applied Hydrogeology (in Greek), Publication of the Technical Chamber of Greece, p. 9/1-9/22, Athens.

Kilili-Polychrinaki, A., 1973, Draft paper of the hydrogeological study of the eastern part of the Thessaloniki plain (in Greek), I.G.M.E., p. 1-24, Thessaloniki.

Konstantinidis, D., 1985, Water resources of Pieria region (in Greek), $3^{\text {rd }}$ Course for the Local Administration, Prefecture of Pieria, p. 41-56, Katerini.

Papageorgakis, I., Koumantakis, I., 1978, Hydrogeological study of Halkidiki and the basins of Anthemountas and Epanomi, Thessaloniki (in Greek), Ministry of Agriculture, p. 59-88, c.5, Athens.

Psilovikos, A., 1985, Development of coastal area and geological structure of Pieria (in Greek), $3^{\text {rd }}$ Course for the Local Administration, Prefecture of Pieria, p. 36-40, Katerini.

Steffens, P., Bruijn, N., Meulenkamp, J., Benda, L., 1979, Field guide to the Neogene of Northern Greece (Thessaloniki area and Strimon basin), Publications of Department of Geology \& Palaeontology, University of Athens, A.35, p. 1-44, Athens.

Todd, D., 1974, Salt water intrusion and its control, Journal of American Water Works Association, V. 66 , p. 180-187, New York. 